SIR,-A letter from Gerschenfeld and others concerning the problems of Chilean scientists under the military rule (Nature, March 29, 1974) has been answered by Eyzaguirre (Nature, July 5, 1974). I feel it my duty to present the view of a Chilean scientist, a witness of the entire process who works in Chile and intends to stay.

Since I do not think Nature to be the proper place for a political argument I shall only say that I disagree entirely with Eyzaguirre's interpretation of what happened in Chile. But neither can $I$ accept his statements of facts. I do not deny the data-which refer to the Catholic University-the problem being rather that he would have others believe that the case of the Catholic University is representative of the Chilean universities. Without saying so explicitly, Eyzaguirre conveys that impression by mixing data of restricted significance with a very general and in my opinion superficial assessment of the Chilean situation before, during and after the military takeover.

According to Eyzaguirre, in the Catholic University "only $3.25 \%$ of faculty members were removed after the coup". The information I have collected for the University of Chile shows that approximately $30 \%$ of the faculty members and $11 \%$ of the nonacademic staff were dismissed after the coup. The significance of this information stands out when one considers that the University of Chile enrols $50 \%$ of the university students compared with $8 \%$ enrolled by the Catholic University.

I have been unable to obtain reliable data concerning the State Technical University, where the military intervention was most drastic. As to the University of Concepción (12.3\% of the student population) the information I have points to at least $30 \%$ of faculty members dismissed. This figure is also a fair estimate for the Austral University ( $2 \%$ of the student population). It has been asserted that the worst hit have been the social sciences, but the private Technical University Santa Maria $3.3 \%$ of the student population) lost about $25 \%$ of its faculty members. I do not have dependable information on the Catholic University of Valparaiso $(5.2 \%$ of the students) and the University of el Norte $(4.2 \%$ of the students).

To sum up: the universities that enrol $75.6 \%$ of the students have lost about $29 \%$ of their faculty members since the military intervention, that is approximately 5,000 people, but dismissals still continue. As to the universities on which I have no consistent data $(24.4 \%$ of the student population) the percentage of faculty members removed is presumably higher, consider- ing that the State Technical University was entirely reorganised and is the second largest university in Chile.

The percentages of faculty members dismissed up to now are estimates based on various sources and might require some correction if reliable information is eventually disclosed to the public. Nevertheless, I trust that my estimates-especially those for the University of Chile-would stand a fair test and anyhow they clearly prove that the Catholic University is an exceptional case.

As to how many of the 130,000 university students have lost their

\section{Letter from Chile}

\section{Dr Luis Izquierdo of the Faculty of Sciences at the University of Chile describes the situation now obtaining in the Chilean universities}

places, dependable information is unavailable at this stage. On the one hand it is still uncertain how many might be allowed to register again; on the other hand, more than one year after the military intervention, students are still being expelled.

Eyzaguirre claims that faculty members removed from the Catholic University had been "engaged exclusively in different forms of political activity". Of course, political activity was not forbidden before the military intervention and nobody should be retrospectively condemned unless proven that he or she was exclusively engaged in these activities, since it is not the role of universities to support full time professional politicians either from the right or left. But. have there been thorough investigations?

It might be again the exceptional case of the Catholic University and hence the low percentage of faculty members removed. It is certainly not the case of the University of Chile in which faculty members were summarily investigated on the basis of secret denunciations. Charges were unspecified and all the defendant could do was to ask for certificates of good conduct from his less scrutinised friends. The procedure has been so irregular that in practice all decisions rested in the "fiscals" appointed by the military rector. I have witnessed much iniustice, persecution and vindictiveness. I also must admit that some "fiscals" accepted their role in this legal farce so as to bring some help to their colleagues in disgrace.

In the State Technical University, University of Concepción and Austral University there was not even the pretence of a legal procedure: the resolutions were based on black lists and faculty members or students were given notice through a standard form which specified no charges.

A decree from the government forbade universities and public institutions to employ faculty members dismissed, so those who had been engaged in research and teaching for years-notably in the basic sciences-had no alternative but to emigrate if they cared to persevere in their work. How can Eyzaguirre deride for practising gauchisme de salon those who left Chile and those lending them a hand from abroad? Of course there are people who have taken advantage of the international benevolence and claimed persecution when really looking for a better job, but they are exceptions and the overwhelming majority could not remain here because they had lost their jobs or felt threatened or could not endure the repressive environment.

The percentage of faculty members dismissed does not show in all its magnitude how serious the loss is for science in Chile. Many more scientists have left because of difficulties encountered in their work, such as disruption of research groups when senior investigators were dismissed, lack of research funds or of up to date libraries. The Chilean Society of Biology includes in its 414 members almost all the biologists at least partially engaged in research; $28 \%$ have left not to return under the present conditions. The situation of the Faculty of Sciences of the University of Chile is even worse. After struggling for 10 years we had succeeded in establishing it on a firm basis. Now, of the 123 faculty members in the department of Mathematics. Physics. Chemistry and Biology, 60 have left the country. Some would probably have been dismissed had thev stayed, others lost hope of pursuing their research work at a satisfactory pace. Those of us who have invested so much of our time in the organisation of this Faculty, bitterly resent a set-back that takes us again to that state of dependence on foreign countries which we had sought to overcome.

The military intervention in Chilean universities has been up to now mainly repressive and has not achieved a new order. Recognised age-old vices of our university system persist in spite of the almost absolute power of present military rectors.

I have written this letter for the sake of truth to the best of my knowledge, convinced as I am that innuendoes, slander and lies from many quarters have corrupted Chilean political life in the last decade causing much individual misery and social distress. 